
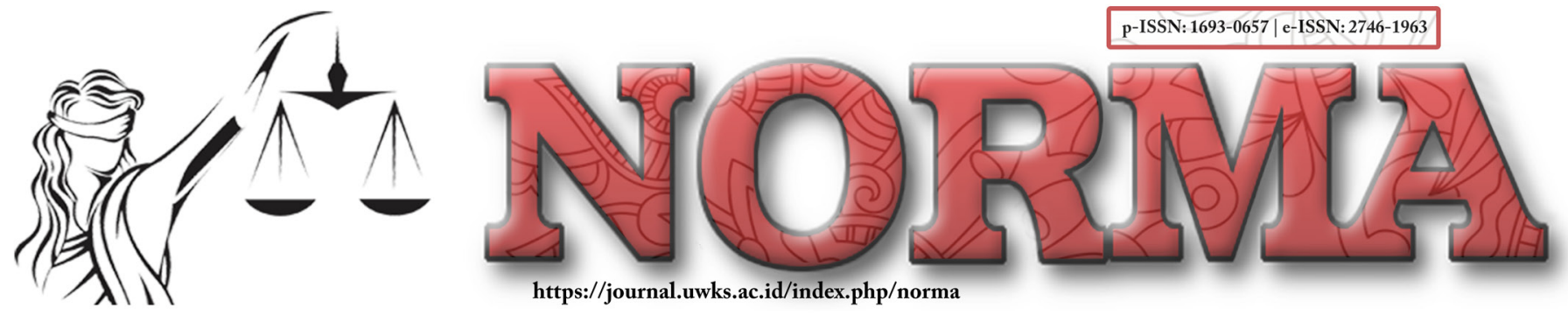

\title{
Implementation Of the Notary's Duties and Positions Regarding the Presence of the Appeaser Refers to Decree Number 65/33-III/ PP-INI/2020 Dated March 17, 2020
}

\author{
Muhammad Firdausy Maulana Witapratama \\ Universitas Narotama \\ e-Mail: firdausymaulanawita@gmail.com
}

\begin{abstract}
:
Concerns about Covid 19 by notaries in doing the Deed. This study aims to examine the Implementation of the Notary Position in Doing Deeds Before and during the Covid-19 Pandemic Period, and to Assess Obstacles in the Duties of Notary Positions in Doing Deeds during the Covid-19 Pandemic Period). The type of research used by the author is descriptive type research. Descriptive research is a problemsolving procedure investigated by describing or describing the current state of the subject and object of research based on existing facts. The results of the research in the Assignment of Notary Positions in Doing Deeds Before and during the Covid 19 Pandemic Period differed from the difference in the health protocol and the presence of the appeasers based on SK Number 65/33-III/ PP-INI/2020 dated March 17, 2020, regarding the matter referred to In the main point of the letter, the Central Management of the Indonesian Notary Association (PP-INI) and all of its staff expressed concern over the massive development of the spread of Covid-19 which directly affected the implementation of the duties of a Notary public in providing services to the public and in this regard, this PP urges all members to follow the health protocols set by the government to overcome the spread of Covid-19.
\end{abstract}

Keywords: CoronaViruses; Notary; Decree.

\author{
Article's History: \\ Received: \\ May 23, 2021; \\ Peer-Reviewed: \\ June 21, 2021; \\ Accepted: \\ July 15, 2021; \\ Published: \\ July 30, 2021. \\ DOI:
}

10.30742/nlj.v18i2.1590

\section{INTRODUCTION}

Notaries are given authority by legislation as in Article 1, number 1 of Law Number 30 of 2014 concerning Notary Positions, as amended by Law Number 2 of 2014 concerning Amendments to Law Number 30 of 2004 concerning Notary Positions (UUJN). A Notary is a public official authorized to do authentic deeds and has other authorities in this Law or based on other laws ${ }^{1}$. Furthermore, Article 15 paragraph (1) of the UUJN stipulates: "The Notary has the power to do an authentic deed regarding all acts, agreements, and stipulations required by laws and/or desired by the interested parties to be stated in an original deed, guaranteeing the certainty of the date of doing the Deed. , keep the Deed, provide Grosse, copies, and quotations of the Deed, all of which are as long as the making of the Deed is not assigned or excluded to other

\footnotetext{
${ }^{1}$ Kelik Pramudya, Pedoman Etika Profesi Aparat Hukum (Yogyakarta: Pustaka Yustisia, 2010), 69.
} 
officials or other people stipulated by Law. A Notary is a public official authorized to do an authentic deed regarding all actions, agreements, and provisions required by laws and/or desired by the interested parties to be stated in a genuine act. ${ }^{2}$

In contrast, other officials are only exceptions." An authentic deed contains the concept of truth where the original Deed proves that the parties have explained what is written in the Deed and that what is described in the Deed is true. An authentic deed can also have perfect evidentiary power because it has three proving forces, namely external, formal, and material. Article 1868 of the Civil Code states: "An authentic deed is a deed made in the form determined by law by or in the presence of a public official authorized to do so at the place where the deed was done." Many fields of work in the world have been affected by the Coronavirus (Covid-19) pandemic due to the need to maintain physical distance to prevent the spread of the virus. All that can be done remotely by going online at home, leaving only work that really can't be done from home, who still have to work outside. All work, including the implementation of the position of a Notary in the current Covid19 pandemic conditions, occupational safety, and health, is one of the essential factors that can affect employee productivity. The risk of contracting the Covid-19 outbreak from clients may occur because the Covid 19 health protocol is not going well. This, of course, can have an impact on employee productivity levels. For this reason, Notaries must be safe by doing preparations by using health protocols as appealed by the central, provincial, and regional governments. That way, the Notary will prepare the steps or prerequisite documents for completeness of the business; this is intended in the process of concluding agreements, transactions, and payment of tax contributions to the parties considering that many government offices are still on holiday ${ }^{3}$.

As regulated in East Java Governor Regulation Number 16 of 2020 concerning Guidelines for Large-Scale Social Restrictions in Handling COVID-19 in each work area Through the meeting, the Head of the Regional Office of the Ministry of Law and Human Rights, together with the meeting participants agreed to coordinate with the Provincial Government East Java related to Notary office operations, among others, so that Notaries / Land Deed Making Officials (PPAT) during the PSBB period can still do deeds and can still open offices following the provisions of the PSBB SOP with a maximum of 5 people, maintain a distance, wear masks, gloves for as long as possible. The Notary's office keeps no crowds. Notaries are held, or their presence is required by the Rule of Law to help and serve the community who desperately need authentic written evidence regarding the circumstances of legal events or actions. On a basis like this, those appointed as notaries must have the spirit to serve the community. For

${ }^{2}$ Fani Martiawan Kumara Putra, "Characteristics of Notary Deeds for Transactions Through Electronic Media," NORMA 17, no. 3 (January 14, 2021): 1-14, https://doi.org/10.30742/nlj.v17i3.1091.

${ }^{3}$ Abdul Ghofur, Lembaga Kenotariatan Indonesia, Perspektif Hukum Dan Etika (Yogyakarta: UII Press, n.d.), 14. 
this service, people who feel a Notary has helped them following the duties of their position can provide an honorarium to the Notary. Therefore a Notary means nothing if the public does not need it ${ }^{4}$.

Notaries, as public officials who carry out the profession in providing legal services to the public, need protection and guarantees to achieve legal certainty. Promises of security and guarantees of achieving legal certainty for implementing the duties of a Notary have been regulated in Law Number 30 of 2004 concerning the Position of a Notary. However, several provisions in the Law are no longer following legal developments and the needs of the community, so that changes need to be made, which are also intended to further emphasize and strengthen the duties, functions, and authorities of Notaries as officials who carry out public services. ${ }^{5}$ Basically, a Notary is a public official who also has a role as a public official. Therefore the problem formulated is how can a Notary carry out his duties and positions during the COVID-19 virus pandemic.

\section{RESEARCH METHOD}

This research is normative, which means that this research examines the side of the legislation itself, not researching social phenomena due to existing legislation. The approach method used in this research is the statutory approach. Therefore, this discussion will refer to the Law.

\section{DISCUSSION}

Article 1 point 1 of Law Number 2 of 2014 concerning Amendments to Law number 30 of 2004 Notary Position (UUJN) defines a Notary as a public official authorized to make authentic deeds and other authorities as referred to in UUJN. The definition given by the UUJN relates to the duties and authorities carried out by a Notary. This means that a Notary has the duty as a public official and has the authority to make authentic deeds and other authorities regulated by UUJN. ${ }^{6}$ Notaries, as public officials who carry out the profession in providing legal services to the public, need protection and guarantees to achieve legal certainty. Therefore, promises of security and guarantees of achieving legal certainty for implementing the duties of a Notary have been regulated in Law Number 30 of 2004 concerning the Position of a Notary. However, several provisions in the Law are no longer following legal developments and the community's needs, so changes need to be made, which are also intended to further emphasize and strengthen the duties, functions, and authorities of Notaries. ${ }^{7}$

${ }^{4}$ Munir Fuady, No Profesi Mulia (Etika Profesi Hukum Bagi Hakim, Jaksa, Advokat, Notaris, Kurator, Dan Pengurus) (Bandung: Citra Aditya Bakti, 2015), 133.

${ }^{5}$ Liliana Tedjosaputro, Etika Profesi Dan Profesi Hukum (Semarang: Aneka Ilmu, 2003), 93.

${ }^{6}$ Ghofur, Lembaga Kenotariatan Indonesia, Perspektif Hukum Dan Etika, 14.

${ }^{7}$ Habib Adjie, Sanksi Perdata \& Administratif Terhadap Notaris Sebagai Pejabat Publik (Bandung: Refika Aditama, 2008), 32 
As positions and professions that have a Code of Position Ethics, Notaries have obligations that must be carried out both based on laws and regulations that specifically regulate Notaries, namely UUJN and other laws and regulations that must be obeyed by notaries, for example, Law Number 40 the Year 2007 regarding Limited Liability Company. The authorities appoint notaries for the public interest. The Law gives the jurisdiction of a Notary in the public interest not for the benefit of the Notary himself but for the benefit of humankind who use his services to carry out legal actions in the form of making authentic evidence. According to the Big Indonesian Dictionary, notaries have restrictions that are defined as orders (rules) that prohibit an action. With the prohibition for notaries, it is intended to guarantee the interests of the people who need the services of a Notary, and bans for Notaries in carrying out their positions are regulated in Article 17 of the UUJN, namely:

1.' Running a position outside the area of the office;

2. Leaving the site of the office more than 7 (seven) working days;

3. Concurrently as a civil servant;

4. Together serving as a state official;

4. Concurrently serving as an advocate;

5. Concurrently serving a s leader or employee of a state-owned enterprise, regional-owned enterprise, or private enterprise;

6. Concurrently serving as Land Deed Making Officer and/or Class II Auction Officer outside the Notary's domicile;

7. Become a Substitute Notary;

8. Perform other work contrary to religious norms, decency, or propriety that can affect the honor and dignity of the position of a Notary.

Suppose the Notary is found to be in violation. In that case, he will receive a sanction in the form of a written warning if he gets a problem that is classified as mild and can be handled by the regional administrator or local wilayah administrator. On the other hand, suppose you have a slightly more severe problem. In that case, you will receive a warning, namely temporary dismissal, where the notice is addressed to a Notary who has legal issues which are judged by the Regional Government or Regional Government as tarnishing the duties and positions of the Notary and can carry out the responsibilities and roles of a Notary after the Decree has been issued. Suppose a Notary has serious problems, for example. In that case, a Notary who has been sentenced to 5 years or less will receive a reward in the form of a respectful dismissal and can be reappointed to continue his duties and Notary position, while for a Notary who commits tax evasion and commits a criminal offense that is not commendable, namely murder, will be punished with dishonorable dismissal and not being able to continue the duties and positions of a Notary until the end of his life. Of course, a Notary who is a professional requires a rule of professional ethics. 
The position of the code of ethics for notaries is critical, not only because a Notary is a profession, but also because of the nature and nature of the work of a Notary that is oriented towards legalization so that it can become the main legal foundation regarding the status of the property, rights, and obligations of a client who uses the services of the Notary ${ }^{8}$. Therefore, in carrying out his duties, a Notary must adhere to the code of ethics for the position of a Notary professionalism. ${ }^{9}$

A deed is a form of a written agreement. According to Subekti, the Deed is not a letter but must be interpreted as a legal act, derived from the word after which in French means action, meaning that a Deed is a form of the existence of a lawful act, or a Deed is a legal act itself. ${ }^{10}$ Article 1 paragraph (7) states that a Notary Deed, from now on referred to as a Deed, is an authentic deed made by or before a Notary according to the form and procedure stipulated in this Law. Article 1 paragraph (8) (9) (10) states that the Minutes of Deed is the original Deeds that include the signatures of the appeasers, witnesses, and Notaries, which are kept as part of the Notary Protocol. A copy of the Deed is a verbatim copy of the entire Deed. At the bottom of the composition of the Deed, the phrase "given as a COPY of the same sound. Deed Quotation is a word-forword quote from one or several parts of the Deed, and at the bottom of the Deed quote the phrase "given as a quote. Article 1 paragraph (12) (13) that the Notary Position Formation determines the number of Notaries needed in a Regency/City. Notary Protocol is a collection of documents that are state archives that must be stored and maintained by a Notary according to the provisions of the legislation.

\section{CLOSING}

\section{Conclusion}

WFH conditions and social distancing will undoubtedly limit the implementation of the duties of a Notary; therefore, in this situation, several alternatives can be taken, including the following: Rearrange the schedule for signing the Deed with the appeasers until conditions allow. Recommend other Notary partners whose needs will enable them to carry out their positions. For agreements, actions, or meetings according to the laws and regulations, the documents can be made private so that the clause "will be made/restated in an Authentic Deed immediately after the Covid-19 emergency is revoked by the Government".

\section{Recommendation}

During the Covid 19 pandemic, Notaries must be wise in applying the Health Protocols used to sign or realize the appeasers so that no one is harmed or infected

${ }^{8}$ Fuady, No Profesi Mulia (Etika Profesi Hukum Bagi Hakim, Jaksa, Advokat, Notaris, Kurator, Dan Pengurus), 133.

${ }^{9}$ Suhrawardi K. Lubis, Etika Profesi Hukum (Jakarta: Refika Aditama, 2008), 35.

${ }^{10}$ Subekti, Pokok-Pokok Hukum Perdata (Jakarta: Intermasa, 2005), 29. 
with Covid 19. In this regard, we urge all members to follow the health protocols set by the government to overcome the spread of Covid-19. In particular, the appeal for Work From Home (WHF) and implementing social distancing. The implementation of the WFH is not a violation of Article 17 of Law 30/2004 concerning the Position of a Notary as amended by Law 2/2014 regarding the prohibition to leave the area of the office for more than seven consecutive working days without a valid reason.

\section{REFERENCES}

Adjie, Habib. Sanksi Perdata \& Administratif Terhadap Notaris Sebagai Pejabat Publik. Bandung: Refika Aditama, 2008.

Fuady, Munir. No Profesi Mulia (Etika Profesi Hukum Bagi Hakim, Jaksa, Advokat, Notaris, Kurator, Dan Pengurus). Bandung: Citra Aditya Bakti, 2015.

Ghofur, Abdul. Lembaga Kenotariatan Indonesia, Perspektif Hukum Dan Etika. Yogyakarta: UII Press, n.d.

Lubis, Suhrawardi K. Etika Profesi Hukum. Jakarta: Refika Aditama, 2008.

Pramudya, Kelik. Pedoman Etika Profesi Aparat Hukum. Yogyakarta: Pustaka Yustisia, 2010.

Putra, Fani Martiawan Kumara. "Characteristics of Notary Deeds for Transactions Through Electronic Media." NORMA 17, no. 3 (January 14, 2021): 1-14. https:// doi.org/10.30742/nlj.v17i3.1091.

Subekti. Pokok-Pokok Hukum Perdata. Jakarta: Intermasa, 2005.

Tedjosaputro, Liliana. Etika Profesi Dan Profesi Hukum. Semarang: Aneka Ilmu, 2003. 